\title{
INFLUENCE OF AGRICULTURAL BIOMASS FLY ASH CEMENT SUBSTITUTION ON THE CARBONATION OF CEMENT AND POLYMER-CEMENT COMPOSITES
}

\author{
WPLYW POPIOŁU LOTNEGO Z BIOMASY ROLNICZEJ \\ NA KARBONATYZACJĘ KOMPOZYTÓW CEMENTOWYCH \\ I POLIMEROWO-CEMENTOWYCH
}

DOI: $10.30540 /$ sae-2020-007

\begin{abstract}
A bstract
Practical use of a new type of combustion waste such as an agricultural biomass fly ash in the building materials requires an assessment of its performance. The paper presents the investigation results on the influence of cement substitution $(5 \%$ and 30\%) by this ash on the cement and polymer-cement composites resistance to carbonation. The composites resistance was assessed on the basis of carbonation process over time (up to 360 days) using the phenolphthalein method. It was found that fly ash from agricultural biomass increases the susceptibility to carbonation of polymer-cement composites to a lesser extent than cement composites compared to composites containing siliceous coal fly ash.
\end{abstract}

Keywords: carbonation, polymer-cement composites PCC, agricultural biomass fly ash, siliceous coal fly ash

\section{Streszczenie}

Praktyczne wykorzystanie $w$ materiałach budowlanych nowego odpadu, jakim jest popiót lotny z biomasy rolniczej, wymaga oceny jego wtaściwości użytkowych. W pracy zaprezentowano wyniki badań wplywu substytucji cementu (5\% i 30\%) tym popiotem na odporność kompozytów cementowych i polimerowo-cementowych na karbonatyzację. Odporność kompozytów oceniono na podstawie przebiegu procesu karbonatyzacji w czasie (do 360 dni) za pomoca metody fenoloftaleinowej. Na podstawie wyników stwierdzono, że popiót lotny z biomasy rolniczej powoduje zwiększenie podatności na karbonatyzację kompozytów polimerowo-cementowych w mniejszym stopniu niż kompozytów cementowych w porównaniu do kompozytów zawierających popiót lotny krzemionkowy.

Słowa kluczowe: karbonatyzacja, kompozyty polimerowo-cementowe, popiót lotny z biomasy, popiót lotny krzemionkowy

\section{INTRODUCTION}

Atmospheric carbonation of concrete materials is a slow process, but has been receiving increasing research interest in recent years due to the aging of a large number of facilities and the associated risk of degradation. Reduction of calcium hydroxide $\mathrm{Ca}(\mathrm{OH})_{2}$ caused by its reaction with atmospheric carbon dioxide $\mathrm{CO}_{2}$ lowers pore solution $\mathrm{pH}$, leading to reinforcing steel depassivation and corrosion $[1,2]$. Damaged reinforced structures should be repaired in such a way as not only to provide further protection of reinforcing steel but also to protect concrete against harmful conditions that caused the need for repair [3, 4]. Among the materials used in the repair works, polymers are a category of high technological importance. In general, repair mortars consist of portland cement, fine aggregate, plasticizers, mineral admixtures (such as silica fume) and polymers (such as styrene-butadiene copolymer SBR, acrylic polymer or vinyl acetate EVA) [5]. The introduction of polymers significantly improves tensile strength, adhesion, flexural strength, chemical 
resistance and durability of mortars and concrete [68]. However, the type and amount of polymers used in the mortars is of great importance for the properties of the final product, in particular for its carbonation resistance. For example, the incorporation of $10 \%$ of epoxy-based polymer was found to decrease mortar carbonation front by $45 \%$ after 14 days' carbonation at $5 \% \mathrm{CO}_{2}$, at $30^{\circ} \mathrm{C}$ and $60 \%$ relative humidity, while for acrylic-based mortars, the carbonation front was only $28 \%$ smaller. At $20 \%$ epoxy emulsion content, the depth of carbonation has been further reduced by up to about $75 \%$ [9]. Research conducted by Nepomuceno A.A. et al. [10] under accelerated carbonation $\left(100 \% \mathrm{CO}_{2}, 20^{\circ} \mathrm{C}, 60-70 \% \mathrm{RH}\right)$ on mortars containing $12 \%$ mixture of acrylic-based polymer and silica fume also showed increased resistance to $\mathrm{CO}_{2}$ due to the reduced number of phases susceptible to carbonation. The same observation was made by Alzahrani M.M et al., who carried out accelerated carbonation $\left(6 \% \mathrm{CO}_{2}, 55^{\circ} \mathrm{C}, 70 \% \mathrm{RH}\right)$ on four types of polymer-cement composites containing polymers with different chemical composition as well as silica fume and/or polymeric fibers. Specimens containing acrylic-based polymer were characterized by complete carbonation after just 2 months. Other types of tested composites were characterized by much better carbonation resistance. The obtained results suggest that the types of polymer used have a significant influence on the carbonation resistance of building materials modified with those polymers. The small depth of carbonation front noted for some of the tested materials may be the result of a more packed microstructure of these materials, due to the use of silica fume, fibers and/or other additives [11]. Silica fume, being a Type I additive, is not reactive with $\mathrm{CO}_{2}$, but acts as a filler that reduces $\mathrm{CO}_{2}$ diffusion in concrete. On the other hand, the role of Type II additives characterized by pozzolanic or latent hydraulic properties, such as the fly ash, microsilica or blast furnace slag, is more complicated and should be considered in the interaction system complex. The microstructure of the hardened cement matrix should be taken under consideration when assessment of the carbonation process of concretes containing such additives [12-14]. Research carried out on the polymer-cement composites containing two types of coal fly ash - siliceous and calcareous have shown that the carbonation resistance of those composites is affected by the type and amount of mineral additive as well as the polymer type [15]. Another type of fly ash from biomass combustion process is a relatively new industrial waste, but its utilization is currently difficult due to legal regulations. However, research to date shows that fly ash from biomass combustion process can be an attractive material for the concrete industry. Research conducted by Wang S. et al. [16] showed that fly ash from biomass have at least the same or much better parameters in terms of strength and durability of concrete compared to traditional fly ash. Similar conclusions follow from studies carried out by Teixeira E.R. et al. [17]. They found out that the building materials containing biomass fly ash are characterized by similar carbonation resistance compared to the traditional fly ash materials. Therefore, it seems that the use of biomass fly ash in buildings materials can bring benefits to those materials and additionally indicates a new way of managing this combustion waste. The purpose of the research presented in this paper was to assess the influence of cement substitution by agricultural biomass fly ash on the change in carbonation resistance of cement and polymer-cement composites. For the comparison purpose, an analogous study was conducted on the composites containing siliceous coal fly ash.

\section{RESEARCH PROGRAM}

Five compositions of cement and polymer-cement composites were designed, differing in type and content of fly ash. Water/binder ratio w/c $=0.5$ was adopted for all compositions. In polymer-cement composites an additional constant polymer content $(\mathrm{p} / \mathrm{c}=15 \%)$ was used. As material variables the type of mineral additive and its amount in relation to the cement mass $(\mathrm{m} / \mathrm{c}=0 \%, 5 \%$ and $30 \%)$ were used. As a polymer modifier, an aqueous dispersion of styrene-acrylic copolymer, recommended by the manufacturer for improving concrete properties, in particular in terms of tensile strength under bending and compression, was used. Two types of fly ash: agricultural biomass fly ash (mixture of oat and wheat biomass) - BM and siliceous coal fly ash PLK were used as a partial cement replacement. The cement binder was CEM I 42.5R portland cement, while as a fine aggregate standard sand in accordance with PN-EN 196-1 [18] was used. Compositions of prepared composites per $1 \mathrm{~kg}$ of the mixture are presented in Table 1. Table 2 summarizes used materials while Table 3 summarized basic physical properties of mineral additives used in this research. 
Table 1. Material composition of designed composites per $1 \mathrm{~kg}$ of mortar

\begin{tabular}{|c|c|c|c|c|c|c|}
\hline Specimen & $\begin{array}{c}\text { Cement, } \\
\mathbf{g}\end{array}$ & $\begin{array}{c}\text { Water, } \\
\mathbf{g}\end{array}$ & $\begin{array}{c}\text { Fine } \\
\text { aggregate, } \\
\mathbf{g}\end{array}$ & $\begin{array}{c}\text { Polymer } \\
\text { dispersion, } \\
\mathbf{g}\end{array}$ & $\begin{array}{c}\text { PLK, } \\
\mathbf{g}\end{array}$ & $\begin{array}{c}\text { BM, } \\
\mathbf{g}\end{array}$ \\
\hline ZN & 222.0 & 111.0 & 667.0 & 0.0 & 0.0 & 0.0 \\
\hline 5BM & 211.0 & 111.0 & 667.0 & 0.0 & 0.0 & 11.0 \\
\hline 5PLK & 211.0 & 111.0 & 667.0 & 0.0 & 11.0 & 0.0 \\
\hline 30BM & 156.0 & 111.0 & 667.0 & 0.0 & 0.0 & 67.0 \\
\hline 30PLK & 156.0 & 111.0 & 667.0 & 0.0 & 67.0 & 0.0 \\
\hline P & 215.0 & 92.0 & 645.0 & 48.0 & 0.0 & 0.0 \\
\hline 5BMP & 204.0 & 92.0 & 645.0 & 48.0 & 0.0 & 11.0 \\
\hline 5PLKP & 204.0 & 92.0 & 645.0 & 48.0 & 11.0 & 0.0 \\
\hline 30BMP & 151.0 & 92.0 & 645.0 & 48.0 & 0.0 & 65.0 \\
\hline 30PLKP & 151.0 & 92.0 & 645.0 & 48.0 & 65.0 & 0.0 \\
\hline
\end{tabular}

Table 2. Materials used in mortars preparations

\begin{tabular}{|l|l|}
\hline Cement binder & \multicolumn{1}{|c|}{ Portland cement CEM I 42.5R (Lafarge) } \\
\hline Fine aggregate & Standard sand \\
\hline Mineral additive & $\begin{array}{l}\text { • Agricultural biomass fly ash (BM) } \\
\text { • Siliceous coal fly ash (PLK) cat. B }\end{array}$ \\
\hline Polymer & $\begin{array}{l}\text { Aqueous dispersion of styrene-acrylic copolymer with } 67 \% \\
\text { solids parts (P) }\end{array}$ \\
\hline
\end{tabular}

Table 3. Density, particle diameters and specific surface area of mineral additives

\begin{tabular}{|l|c|c|}
\hline \multicolumn{1}{|c|}{ Property } & Agricultural biomass fly ash & Siliceous coal fly ash \\
\hline Density, $\mathrm{g} / \mathrm{cm}^{3}$ & 2.53 & 2.04 \\
\hline$D_{\text {min }^{\prime}} \mu \mathrm{m}$ & 0.17 & 0.17 \\
\hline$D_{\text {max }^{\prime}} \mu \mathrm{m}$ & 67.52 & 51.50 \\
\hline Average, $\mu \mathrm{m}$ & 16.40 & 11.20 \\
\hline$D_{50^{\prime}} \mu \mathrm{m}$ & 13.20 & 11.60 \\
\hline$D_{90^{\prime}} \mu \mathrm{m}$ & 29.90 & 22.80 \\
\hline S.P., $\mathrm{cm}^{2} / \mathrm{cm}^{3}$ & 15528 & 29198 \\
\hline
\end{tabular}

The dry ingredients were mixed together to form a homogeneous mixture, followed by the addition of the aqueous polymer dispersion and the remaining amount of water that was needed to obtain the w/c ratio. After molding, the specimens were covered with plastic sheet and set for 24 hours. One-day samples were removed from the molds and subjected to further curing. Polymer-cement composites were immersed in water for 5 days and were subsequently dried in the air for 22 days. This treatment allows the formation of a polymer-cement matrix proceeded by cement hydration at the early age. The remaining specimens, without polymer addition, were stored in water throughout the entire curing time. After the age of 28 days, the specimens were moved to a carbonation chamber - in which $\mathrm{CO}_{2}$ concentration was kept at $1 \%$, with a temperature of $21^{\circ} \mathrm{C} \pm 1{ }^{\circ} \mathrm{C}$ and a relative humidity of $60 \% \pm 10 \%$. Carbonation resistance was determined in accordance with the European Standard PN-EN 13295: 2005 [19]. The test was carried out on the rectangular specimens with dimension of $40 \times 40 \times 160 \mathrm{~mm}$.

\section{RESULTS}

As a preliminary study the properties of fresh mortar mixes were tested. The results of this measurements are presented in Table 4. The plasticity of cement mortars is not affected by presence of fly ashes except for mortars containing $30 \%$ of siliceous fly ash. Its plasticity decreased by about $20 \%$, compared to unmodified cement mortar. Both biomass fly ash and siliceous fly ash changed the consistency of cement mortars. For example mortars containing 30\% BM were characterized by $34 \%$ lower consistency while $30 \%$ PLK decreased consistency of about $49 \%$, compared to unmodified cement mortar. Cement replacement by fly ashes did not influence the consistency of polymer - cement mortars. Biomass fly ash slightly increased plasticity of PCC mortars while siliceous fly ash lowered its plasticity, compared to unmodified PCC mortar. Cement replacement by fly ashes did not change air content of tested mortars. Obtained results are differ slightly and in most of the cases is within the error of the measuring instrument.

Table 4. Properties of fresh mortar mixes.

\begin{tabular}{|c|c|c|c|}
\hline Specimen IProperty & Consistency, cm & Plasticity, cm & Air content, \% \\
\hline ZN & 5.3 & 13.5 & 4.9 \\
\hline 5BM & 4.9 & 13.5 & 5.0 \\
\hline 5PLK & 6.0 & 14.1 & 4.5 \\
\hline 30BM & 3.5 & 14.0 & 4.0 \\
\hline 30PLK & 2.7 & 10.9 & 4.9 \\
\hline P & 11.3 & 26.5 & 0.8 \\
\hline 5BMP & 11.5 & 29.5 & 1.3 \\
\hline 5PLKP & 11.5 & 24.5 & 0.7 \\
\hline 30BMP & 11.5 & 30.0 & 1.4 \\
\hline 30PLKP & 11.2 & 24.5 & 1.3 \\
\hline
\end{tabular}

The depth of carbonation is presented in Figure 1 as a function of the duration of $\mathrm{CO}_{2}$ exposure from 14 to 360 days. Phenolphthalein was sprayed on the fractured surface of the specimen and the carbonation 
depth was measured on the four edges at an accuracy of $0.1 \mathrm{~mm}$ (Fig. 2). The average of the measurements was presented. Because the test was conducted on the rectangular samples with dimension of $40 \times 40 \times 160 \mathrm{~mm}$, the maximum measurable value of the carbonation depth was $20 \mathrm{~mm}$.

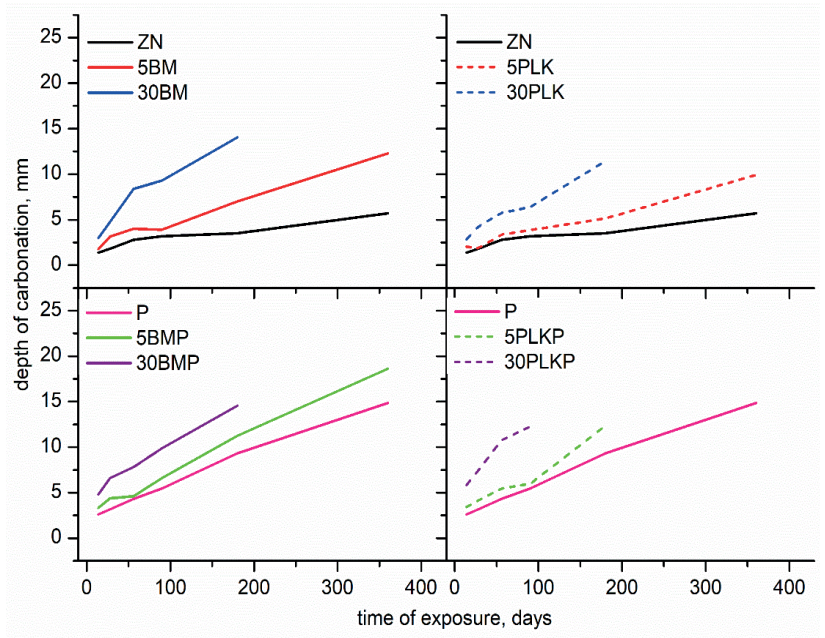

Fig. 1. Carbonation depth of tested specimens
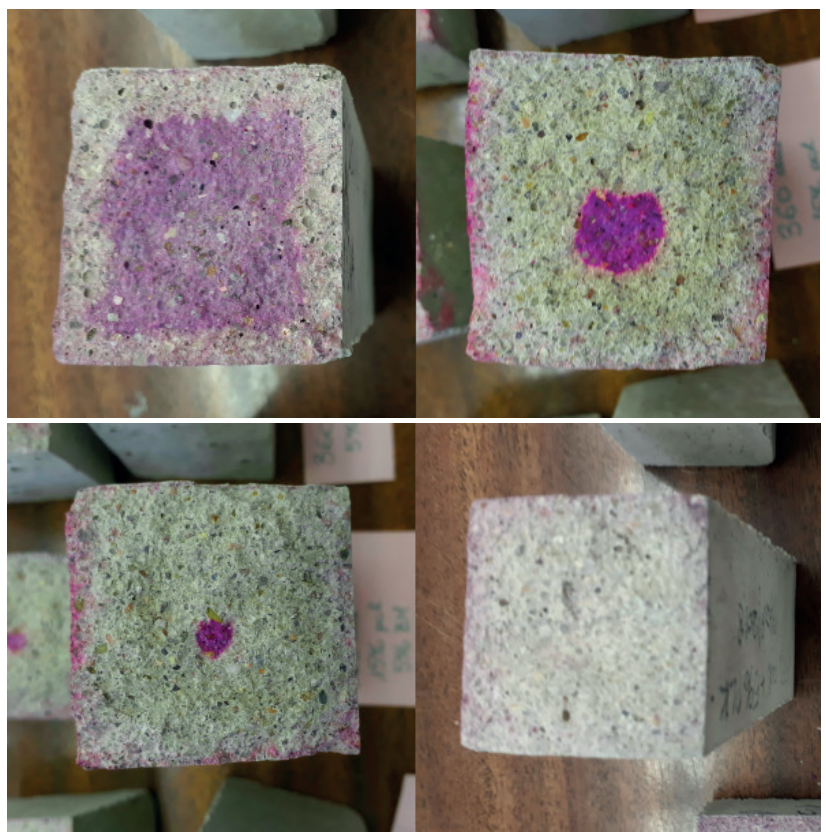

Fig. 2. Specimens after 360 days of $\mathrm{CO}_{2}$ exposure

Substituting cement with fly ash was found to decrease carbonation resistance of the composite mortars. The reduction in carbonation resistance of composites has been observed with the increased fly ash content, irrespective of the fly ash. The cement substitution with $5 \%$ of biomass fly ash doubled the carbonation depth after 360 days of exposure, and $30 \%$ addition of biomass fly ash as much as 4 times after 180 days (after 360 days the carbonation depth exceeded $20 \mathrm{~mm}$ ), compared to standard mortar $(\mathrm{ZN})$. A similar relationship was observed when comparing mortars containing biomass fly ash with mortars with siliceous coal fly ash. For example, carbonation depth after 180 days for composites containing $30 \%$ of siliceous coal fly ash was $11.4 \mathrm{~mm}$, while with $30 \%$ biomass fly ash it was about $20 \%$ higher. PCC composites containing biomass fly ash were characterized by reduced resistance to carbonation compared to unmodified PCC composites.

$5 \%$ cement substitution by biomass fly ash increased the carbonation front depth by $30 \%$. PCC composites with $30 \%$ biomass fly ash were characterized by complete neutralization after 180 days. However, PCC mortars with biomass fly ash were observed with a higher carbonation resistance compared to PCC mortars with siliceous coal fly ash, because in the latter, their complete neutralization took place after 90 and 180 days for $30 \%$ and $5 \%$ ash, respectively. It should be noted though that polymer modification of cement mortar alone clearly deteriorated its carbonation resistance. Unmodified polymer-cement composites after 360 days were characterized by almost three times higher carbonation depth compared to standard mortar.

Since the cement substitution by fly ash deteriorated the carbonation resistance of polymer-cement composites to a lesser extent than cement mortars, the research was extended with additional compositions of PCC composites with $10 \%$ and $25 \%$ fly ash content in relation to the cement mass (10BMP, 25BMP, 10PLKP oraz 25PLKP). The carbonation depth was measured after 56 days and the obtained results are shown in Figure 3.

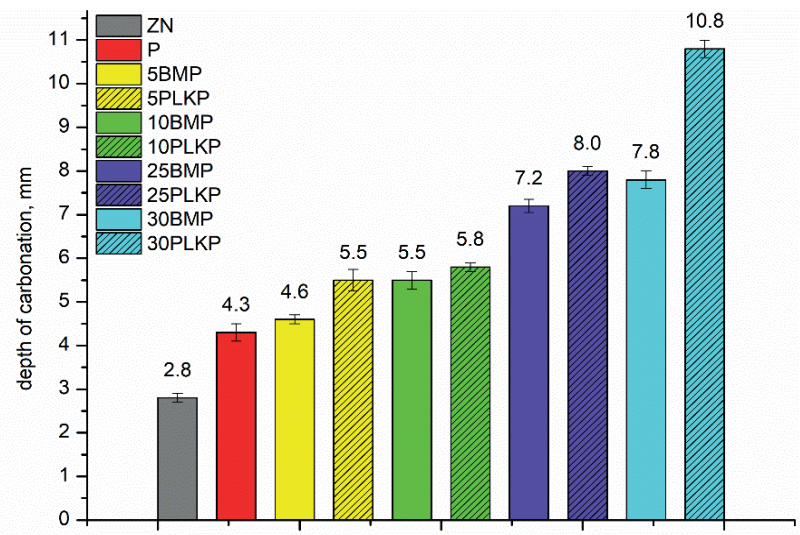

Fig. 3. Carbonation depth after 56 days of $\mathrm{CO}_{2}$ exposure

The addition of 5\% biomass fly ash did not cause a clear change in the carbonation resistance compared 
to the unmodified PCC. The PCC composites containing $10 \%$ of biomass fly ash were characterized by about $25 \%$ higher carbonation depth reaching the same depth as PCC with 5\% siliceous fly ash. The greatest impact of the type of mineral additive used on the carbonation of PCC composites can be observed in the case of mortars with $30 \%$ fly ash content. PCC composites with $30 \%$ biomass fly ash were characterized by a smaller carbonation depth $(7.8 \mathrm{~mm}$ ) compared to mortars containing the same amount of siliceous fly ash $(10.8 \mathrm{~mm})$.

\section{CONCLUSION}

The susceptibility of building materials to carbonation can be assessed on the basis of a carbonation test by the phenolphthalein method. The tested specimens were subjected to accelerated carbonation in a $1 \% \mathrm{CO}_{2}$ chamber, with a temperature $21^{\circ} \mathrm{C} \pm 1{ }^{\circ} \mathrm{C}$ and a relative humidity of $60 \% \pm 10 \%$. The research shows that the presence of agricultural biomass fly ash (mixture of oat and wheat biomass) in cement mortars increase mortar carbonation to a greater extent than when using siliceous fly ash.
The depth of the carbonation front increased with the increase of the mineral additive content in the mortar and also with the duration of carbonation. The presence of agricultural biomass fly ash in polymercement composites also increased their susceptibility to carbonation, but to a much lesser extent than siliceous fly ash. After 56 days of exposure to $\mathrm{CO}_{2}$ biomass fly ash substitution up to $10 \%$ of cement mass in PCC mortars does not cause a clear change in the carbonation resistance of those composites compared to the unmodified PCC. However, it should be noted that the mortar modification with aqueous dispersion of styrene-acrylic copolymer alone clearly deteriorated its carbonation resistance. The presented in this paper research clearly shows that the carbonation resistance of cement and polymer-cement composites depends on the type and amount of mineral additives used. When considering carbonation resistance of building materials, agricultural biomass fly ash can be used as mineral additives in polymer-cement composites instead in cement composites but further investigation should be done to determined its compatibility with other types of polymers modifiers.

\section{REFERENCES}

[1] Johannesson, B. and P. Utgenannt, Microstructural changes caused by carbonation of cement mortar. Cement and Concrete Research, 2001. 31(6): p. 925-931.

[2] Papadakis, V.G., C.G. Vayenas, and M.N. Fardis, Fundamental Modeling and Experimental lnvestigation of. ACI Materials Journal, 1991. 88(4).

[3] Emmons, P. and A. Vaysburd, System concept in design and construction of durable concrete repairs. Construction and Building Materials, 1996. 10(1): p. 69-75.

[4] Vaysburd, A. and P. Emmons, How to make today's repairs durable for tomorrow corrosion protection in concrete repair. Construction and Building Materials, 2000. 14(4): p. 189-197.

[5] Ohama, Y., Polymer-based admixtures. Cement and Concrete Composites, 1998. 20(2-3): p. 189-212.

[6] State of the art report on polymer-modified concrete, in ACI Manual of Concrete Practice, Part-5, A.C. Institute, Editor. 2000: Famington Hills, USA.

[7] Ohama, Y., Principle of latex modification and some typical properties of latex-modified mortars and concretes adhesion; binders (materials); bond (paste to aggregate); carbonation; chlorides; curing; diffusion. Materials Journal, 1987. 84(6): p. 511-518.

[8] Mirza, J., M. Mirza, and R. Lapointe, Laboratory and field performance of polymer-modified cement-based repair mortars in cold climates. Construction and Building Materials, 2002. 16(6): p. 365-374.

[9] Aggarwal, L., P. Thapliyal, and S. Karade, Properties of polymer-modified mortars using epoxy and acrylic emulsions. Construction and Building Materials, 2007. 21(2): p. 379-383.

[10] Nepomuceno, A.A. and C. Andrade, Steel protection capacity of polymeric based cement mortars against chloride and carbonation attacks studied using electrochemical polarization resistance. Cement and Concrete Composites, 2006. 28(8): p. 716-721.

[11] Al-Zahrani, M., et al., Mechanical properties and durability characteristics of polymer-and cement-based repair materials. Cement and Concrete Composites, 2003. 25(4-5): p. 527-537.

[12] Wieczorek, G., J. Bryłka, and M. Bołtryk, Korozja zbrojenia inicjowana przez chlorki. Cement Wapno Beton, 2002. 7(69, nr 4): p. 158-162.

[13] Woliński, P., P. Woyciechowski, and G. Adamczewski, Effect of calacreous fly ash on the carbonation progress in concrete. Mater. Bud, 2015. 12: p. 24-25. 
[14] Brandt, A., et al., Zastosowanie popiołów lotnych z kottów fluidalnych w betonach konstrukcyjnych. Studia z zakresu inżynierii, 2010. 72: p. 339-351.

[15] Woliński, P., et al. The influence of the mineral additives on the carbonation of cement composites. in MATEC Web of Conferences. 2018. EDP Sciences.

[16] Wang, S. and L. Baxter, Comprehensive study of biomass fly ash in concrete: Strength, microscopy, kinetics and durability. Fuel Processing Technology, 2007. 88(11-12): p. 1165-1170.

[17] Teixeira, E.R., et al., Recycling of biomass and coal fly ash as cement replacement material and its effect on hydration and carbonation of concrete. Waste Management, 2019. 94: p. 39-48.

[18] PN-EN 196-1 Methods of testing cement. Determination of strength.

[19] PN-EN 13295:2005 Products and system for the protection and repair of concrete structures - test methods - determination of resistance to carbonation. 2005.

\section{Acknowledgments:}

The works were financed by the Department of Building Materials Engineering, Faculty of Civil Engineering, Warsaw University of Technology, Warsaw, 00-637 Poland

\section{Podziękowania:}

Praca została sfinansowana przez Zaktad Inżynierii Materiałów Budowlanych, Wydziat Inżynierii Ladowej, Politechnika Warszawska, Warszawa, 00-637 Polska 